\title{
The InVISIBLE HAND Plays Dice: EVENTUALITIES IN RELIGIOUS MARKETS
}

\author{
PANU POUTVAARA \\ ANDREAS WAGENER
}

CESIFO WORKING PAPER NO. 1238

CATEGORY 9: INDUSTRIAL ORGANISATION

JULY 2004 


\title{
THE INVISIBLE HAND PLAYS DicE: EVENTUALITIES IN RELIGIOUS MARKETS
}

\begin{abstract}
Religious participation is much more widespread in the United States than in Europe, while Europeans tend to view sects more suspiciously than Americans. We propose an explanation for these patterns without assuming differences in preferences or market fundamentals. Religious markets may have multiple equilibria, suggesting that observed differences in religious structures may merely be eventualities. Further, equilibria with more sects result in higher welfare and lower membership costs, as secular societies tend to host on average more demanding sects. Our main methodological contribution to the theory of religious markets is endogenizing simultaneously supply and demand of spiritual services.
\end{abstract}

Keywords: sects, religion, tithes, religious markets.

JEL Code: Z12, L89, J24, D71.

Panu Poutvaara

Centre for Economic and Business Research

(CEBR)

Langelinie Allé 17

2100 Copenhagen

Denmark

panu.poutvaara@cebr.dk
Andreas Wagener

Department of Economics

University of Vienna

Hohenstaufengasse 9

1010 Vienna

Austria

andreas.wagener@univie.ac.at

We thank Mikael Priks and participants at the European Public Choice Society Annual Meeting in Berlin, April 15-18, 2004, for useful comments. 


\section{Introduction}

Religious attitudes and participation differ largely between the United States and Europe. In the United States, more than 40 percent of population attend church weekly and religious participation has increased steadily over the last two hundred years. Europe is much more secular: In Denmark, Finland, Norway and Sweden, less than 10 percent of population attend church weekly, in the United Kingdom around 15 percent, and in Germany 16 percent (Iannaccone (1998); Bruce (1999); GESIS (2004)).

Also political attitudes and public opinion towards the necessity or desirability of policing religious groups tend to differ largely between Europe and the United States (Kent (2001)). In general, Europeans have a more cautious attitude towards new religious groups while Americans place a much higher value on religious laissez-faire. E.g., a recent report by a German governmental Enquete Commission (1998) on religious groups and psycho-groups actively calls for regulation and surveillance of sects and cults - which is regarded by politicians in the United States as an infringement of religious rights. ${ }^{1}$ On the contrary, many European politicians dismiss the lenient American attitude as ignorant and defend their interventions on the grounds of protecting potential sect victims. ${ }^{2}$

So far, the economic theory of religion has not provided an entirely convincing explanation for the large differences in religious participation and attitudes towards non-mainstream religious groups. The dominant strand of the theory of religious markets, the so-called supply-side theory, views the demand for religion as largely invariant across time and space such that differences in religious patterns must be attributed to differences on the supply sides of religious markets (Stark and Bainbridge (1996)). Supply-side theory argues that religious markets in Europe are dominated by "lazy" monopoly churches without entrepreneurial zeal while the United States hosts large numbers of competitive sects and religious groups that actively vie for devotees. Openness and competitive pressures in American religious markets

\footnotetext{
${ }^{1}$ E.g., the United States Department of State writes: "Several [German] states have published pamphlets detailing the ideology and practices of nonmainstream religions. States defend the practice by noting their responsibility to respond to citizens' requests for information about these groups. While many of the pamphlets are factual and relatively unbiased, others may harm the reputations of some groups through innuendo and inclusion in a report covering known dangerous cults or movements" (International Religious Freedom Report 2002, p. 3).

${ }^{2}$ E.g., the chairman of a French ministerial mission to combat the influence of cults, Alain Vivien, declared: "No one can forbid us to take action against sects in the interests of human rights. This point of view is particularly absurd when these movements flout the most elementary rights" (The Guardian, June 14, 2000).
} 
serve the needs of religious customers better and thereby generate higher participation and consumer satisfaction than drowsy religious dinosaurs in Europe. ${ }^{3}$ While quite persuasive, the current version of supply-side theory is not able to resolve a number of intriguing puzzles in religious markets. E.g., it cannot explain why more fervent sects do not overtake "monopoly churches" in Western Europe where religious competition has been free for at least several decades. Furthermore, supply-side theory has trouble with explaining why there are also vast differences in religious market structures across the United States - although the same openness and rights of religious freedom apply in all states (also see Bruce (1999) on that point). Finally, supply-side theory cannot (and, to be fair, does not try to) explain why attitudes towards the regulation of religious markets differ so largely across countries that are equally strict in their laïzism or their separation of church and state like the United States and France. ${ }^{4}$

In this paper, we propose a formal model of a religious market from which a possible explanation for these phenomena emerges. In that model, both demand and supply are endogenous: Customers (i.e., potential members of religious groups) have religious wants. Entrepreneurs in the religious market incur some costs in establishing spiritual services and, in return, demand for compensation that depends on their personal characteristics. ${ }^{5}$ More charismatic leaders are able to collect larger tithes, giving them a comparative advantage in establishing a sect. ${ }^{6}$ Unlike many contributions to the economics

\footnotetext{
${ }^{3}$ Studies by Iannaccone (1991), Stark and Iannaccone (1994), Stark et al. (1995), and Iannaccone (1998) corroborate a positive correlation between rates of religious diversity and religious participation. Voas et al. (2002) and Bruce (1999) dismiss these observations as a mere statistical artefact.

${ }^{4}$ According to Chaves and Cann (1992) and Messner (1999), the United States, Canada, Australia, France, the Netherlands and, surprisingly, Ireland are the Western countries where religion is most deregulated and church-state separation is strictest.

${ }^{5}$ Viewing religious groups as driven by monetary incentives dates at least back to Adam Smith (1999[1776], pp. 376f). Empirical evidence ranges from the medieval Catholic church to U.S. "televangelist" Jim Bakker who diverted money collected from his followers to pay for private luxuries, including an air-conditioned dog-kennel. See Iannaccone (1998, pp. 1484f) for a brief survey on entrepreneurial models of religious groups.

${ }^{6}$ Whether the question is of a congregation belonging to a larger denomination, a church, a sect or a cult, we refer to those groups simply as "sects", and we use the word in a neutral sense. In general, the use of the word "sect" is multifarious. In a theological meaning a "sect" refers to a group which follows dogmas or religious practices that deviate, or have been declared to deviate, from established or official doctrines; with the fading of faith monopolies this distinction has, however, become more or less vacuous. The social sciences define a sect as a small, exclusive, mostly religious or ideological group that demands substantial commitment of its followers and which places special emphasis on the group's otherness from its environment (Abercrombie et al. (2000), pp. 371f). European colloquial use of language often adds to this the degradation and bonding of individuals
} 
of religion (e.g., the seminal contribution by Azzi and Ehrenberg (1975)), our paper focuses on life on earth, without taking a stance on the existence of afterlife. The perceived potential benefits in afterlife are taken as a given intrinsic motivation for sect membership.

Our analysis suggests that equilibria in religious market are generally not unique. In particular, both a "secular" (European-type) equilibrium - characterized by a small number of small sects with highly charismatic leaders demanding large tithes of their flock and an otherwise low religious participation - and a "sectarian" (American-type) equilibrium - where a substantial part of the population is distributed over a large number of on average rather low-demanding sects - might emerge. More generally, the same set of initial conditions (represented by distributions over consumer preferences and the characteristics of the suppliers of religious services) might give rise to largely different outcomes with respect to the religious participation in the population, the number of active religious groups in the market, the extent of their activities, and their membership costs. This observation lends to a new "explanation" for observed diversity in religious patterns: that of a mere eventuality or, for believers, an act of Providence.

As a corollary, cross-country differences in religious market equilibria need not be due to differences in supply or demand conditions, different institutional settings, differences in the populations' spiritual neediness or susceptibility to religious marketing etc.; they simply could be more or less random equilibrium realizations in a market game with indeterminate outcome. In particular, this might have occurred in the United States where one finds a puzzling (and growing) religious diversity across the states. Although the same constitutionally guaranteed rules for freedom of religion apply all over the nation (i.e., the religious market is "competitive" everywhere), the states exhibit large variations in observed religious structures. ${ }^{7}$ Moreover, Bruce (1999, Chs. 3 and 4) lists plenty of observations, both historical and recent, from the United States and Europe, that the supply siders' prediction of a

or the preaching of intolerance - a perspective that we do not endorse here.

${ }^{7}$ In few states there is a dominant denomination (Utah with 71 percent Latter Day Saints, Rhode Island with 63 percent Catholics) while the largest denomination in West Virginia, the United Methodist Church, covers a mere 10 percent of the population (adherents.com (2003)). In Oregon, Washington, Idaho and Wyoming, 20 percent or more of population have no religion, constituting the largests "religious" group. In North Dakota, Alabama, and Mississippi, only seven percent or less have no religion (ARIS (2001)). Counting only for major religious groups (in which at least 0.5 percent of the populace assemble), there are more than 20 such groups in Oregon while North Dakota and New Hampshire only host twelve (ARIS (2001)). Both in Oregon and Vermont, around 21 percent of the population do not adhere to any religion; Vermont is, however, largely catholic (38 percent) while Oregon's population is split over numerous denominations. 
positive association between pluralism and religious vitality is questionable. While Bruce (1999) uses these observations to dismiss the rational-choice model of religion as patently flawed, our formalization of religious markets with multiple equilibria suggests that the rational-choice approach is wellsuited to derive a manifold of empirically relevant predictions, and therefore ought to be refined, rather than dismissed, as a tool for analyzing religion. ${ }^{8}$

A further implication of our model is that the smaller is the number of sects that are active in a market equilibrium the higher are the demands which these sects impose on their (relatively few) members. ${ }^{9}$ I.e., in more secular societies sects impose, on average, heavier burdens on their small flock than in societies with higher rates of religious participation. Hence, fears that sect leaders might "abusively" extract significant resources from their members would then seem, on average, more justified in a secular than in a sectarian equilibrium. Different religious equilibria might therefore also frame the perception of sects and, as a consequence, policy attitudes towards religious groups.

It should be noted, however, that our model does not provide any support for a policy of limiting competition in the religious market. Rather to the contrary, we show that, if there are multiple equilibria, the one with the largest number of active sects is the optimal one from a welfare perspective.

Our paper is organized as follows. In Section 2, we present a stylized model of a religious market. Consumers decide on sect membership in a utility-maximizing manner, and sect leaders, whose charismatic qualities are unknown to consumers upon entrance into the sect, strive for profit maximization. As shown in Section 3, market equilibria in this model are not necessarily unique. However, in Section 4 we show that under certain conditions equilibria can be ranked in terms of social welfare. Section 5 summarizes our findings and concludes.

\section{A Model of Religious Markets}

There is a continuum of potential sect leaders who can offer religious services to their customers. If a potential sect leader establishes a sect, he or she

\footnotetext{
${ }^{8}$ Our results are complementary with a recent contribution by Barros and Garoupa (2002). They introduce spatial-location models into the economics of religion, taking entry decisions as given.

${ }^{9}$ In this paper, we only consider contributions in the form of tithes. Apart from asking for money, religious groups can and do require a lot of their members also along other dimensions (Iannaccone (1992b), Berman (2000)). They impose significant costs in terms of sacrifice, abstinence from certain reprehensible pleasures, strict morality and even stigma upon their members and, in the extreme, may even drive them to martyrdom.
} 
has to incur a fixed entry cost $d$, consisting of the costs of fabricating a doctrine, using time to convince members of it, and opening a church or temple. The entry cost is net of any psychological or spiritual satisfaction that a sect founder might gain from establishing a sect. We therefore need not model religious motivations of sect leaders explicitly. They operate as profit maximizers and earn their revenues by charging contributions from their members, but only long after having attracted them to their sect.

Sect leaders differ in their "charisma" which we use as a generic term for all attributes of a sect leader that make membership in his or her sect attractive for potential targets: personal charm, negotiating skills, telegenic appearance, sermonic fervor, and convincingness. Charisma determines how much the sect leader can request from sect members. Unlike for other social groups, the ability of sect leaders to charge contributions from members does not derive from a binding contract, signed upon entrance into the sect, but from associating exit or expulsion from the sect with certain religious or social costs (after-life punishment, loss of the social network etc.) that sect members wish to avoid. For believers, a threat of afterlife punishment is credible; individuals unwilling to adhere to the sect's rules and discipline risk the wrath of God, damnation, or other heavenly sanctions. ${ }^{10}$

For sake of simplicity, we set exit costs from a sect to be equal in value to charisma $c$. At the time of establishing the sect and of attracting members, charisma of sect leaders is their private knowledge. The charisma of potential sect leaders is distributed with continuous density $f(c)$ over a closed interval $[0, \bar{c}]$. By $F(c)$ we denote the attending cumulative distribution function.

There is a continuum of consumers who might be interested in joining a sect. Denote by $h$ the willingness to pay for the religious benefits and services associated with becoming a sect member and assume that $h$ is distributed across the population with density $g(h)$ and support $[\underline{h}, \bar{h}]$. Correspondingly, denote by $G(h):=\int_{h}^{h} g(\xi) d \xi$ the cumulative distribution function of $h$. Without loss of generality, we assume that the mass of potential members and of potential leaders both are equal to one.

The sequence of events unfolds as follows: First, sect leaders, who have private, but non-verifiable information about their charisma decide on whether to establish a sect. Consumers then decide whether or not to join a sect. By experience, those who joined learn the charisma of their sect leaders, each of whom then asks his or her members for contribution (tithes). Sect members

\footnotetext{
${ }^{10}$ It is well-known from "Pascal's Wager" (Pascal 1995[1660], § 233) that such a threat need not be trustworthy with probability one, but will make members of religious groups obey to the obligations of the sect even if only a positive probability is attached to a sufficiently high loss in the post-mortal quality of life.
} 
then choose whether to pay what is asked or to exit the sect, incurring a psychological exit cost.

The utility $u$ of type- $h$ consumer if (s)he enters a sect whose leader has charisma $c$ is given by

$$
u= \begin{cases}h-t(c) & \text { if he stays in the sect and pays tithes } \\ h-x(c) & \text { if he leaves the sect, }\end{cases}
$$

where $t$ and $x$ denote tithes and exit costs, respectively.

In (1) we assume that the religious gross benefits of sect membership (establishing a relationship to God, obtaining ethical guidelines, being baptized etc.) are irredeemable, i.e., they would not be lost upon exit from the sect. Religious net benefits in case of leaving the sect may differ, as a charismatic sect leader may convince sect members of after-life punishment in case they leave (also see footnote 11 below). This also reflects the typical time pattern of sect membership: first members receive services without paying and become absorbed, and only after that they are asked to pay.

In (1) it is further assumed that neither tithes nor exit costs differ across individuals. The first assumption can be justified by the inability of sects to effectively differentiate the contributions they levy according to their members' individual willingnesses to pay, which is private information. The second assumption is made for simplicity. If the willingness to pay for sect membership depended on individual-specific random variable and sect leader's charisma, then sect leaders would choose the tithe they ask to maximize expected payments from their members, taking into account that this may lead into exit by those with lowest willingness to pay.

We assume that exit costs $x$ are strictly increasingly related to the charisma level of the sect leader. For simplicity, but without any loss of generality we will henceforth assume that exit costs are (numerically) equal to the charisma level of the sect leaders from whose sect the members exit: $x(c)=c$. In an equilibrium, a profit-maximizing sect leader will then demand contributions equal to what would be his members' exit cost, i.e., contributions (numerically) equal charisma: $t(c)=x(c)=c$. This also ensures that no sect member will ever leave a sect. ${ }^{11}$

Upon entrance into a sect, charisma levels of sect leaders are still unknown to potential sect members. Hence, membership decisions are based

\footnotetext{
11 We could straightforwardly add to our model benefits from sect membership that positively depend on the charisma of the sect leader and that would be foregone upon exit from the sect. Denoting such benefits by $b(c)$, individual $h$ 's utility (1) from becoming and staying a sect member would then be $h+b(c)-t(c)$, while the decision to first join and later leave a sect would yield $h-x(c)$. Profit maximizing sect leaders then would never charge their sect members in excess of $t(c)=x(c)+b(c)$ which is strictly increasing in $c$ and would, therefore, result in an equivalent specification of our model.
} 
on expectations about membership and exit costs (taking into account, of course, that these are related one-to-one to charisma levels). Denoting by $C$ the expected charisma level in the religious market and employing the reasoning just outlined, consumer $h$ expects his or her utility (1) from joining a sect to be equal to

$$
U(h):=E[u(h)]=h-C,
$$

where the expectation is taken with respect to the distribution of charisma levels for active sects. Observe that while each individual consumer treats $C$ as exogenous, it is endogenous on the level of economy. Normalizing everybody's utility when staying outside any sect to zero, individual $h$ will join a sect whenever $U(h) \geq 0$. If individual $h$ joins a sect, so will all individuals of types $h^{\prime}>h$ (at a given level of $C$ ). As charisma of different sect leaders is still private knowledge, those wishing to enter a sect are equally distributed amongst all sects.

The expected costs of sect membership are determined by the lower bound of charisma in the religious market:

$$
C(\hat{c})=E(c \mid c \geq \hat{c})=\frac{1}{1-F(\hat{c})} \int_{\hat{c}}^{\bar{c}} c f(c) \mathrm{d} c .
$$

Here, $\hat{c}$ denotes the level of charisma above which establishing a sect pays off for the sect leader. With this charisma level, a sect leader makes zero profit. Profits for a sect leader with charisma $c$, amount to

$$
\frac{n}{1-F(\hat{c})} \cdot c-d
$$

with $n$ as the mass of individuals who join a sect at all, i.e.:

$$
n=\int_{h: U(h) \geq 0} g(h) \mathrm{d} h .
$$

Denoting by $\hat{h}$ the marginal individual to join a sect, equilibrium in the religious market is thus characterized by a pair $(\hat{c}, \hat{h})$ satisfying

$$
\begin{aligned}
\alpha(\hat{h}, \hat{c}) & :=\hat{h}-\frac{1}{1-F(\hat{c})} \cdot \int_{\hat{c}}^{\bar{c}} c f(c) \mathrm{d} c=0 \\
\beta(\hat{h}, \hat{c}) & :=\frac{\hat{c}}{1-F(\hat{c})} \cdot \int_{\hat{h}}^{\bar{h}} g(h) \mathrm{d} h-d \\
& =\frac{1-G(\hat{h})}{1-F(\hat{c})} \cdot \hat{c}-d=0 .
\end{aligned}
$$


The first condition is the zero-utility constraint for the marginal sect member, requiring that expected membership costs equal the willingness-to-pay for membership. The second condition is the break-even condition for the marginal sect leader, requiring that the costs $d$ for setting up the doctrine equal the sect leader's revenues. Revenues are calculated as (average) sect size $(1-G(\widehat{h})) /(1-F(\widehat{c}))$ times the membership fee $\widehat{c}$.

\section{$3 \quad$ Existence and Multiplicity of Equilibria}

Observe that both loci $\alpha=0$ and $\beta=0$ describe upward-sloped graphs in the $(\hat{h}, \hat{c})$-space. Namely:

$$
\begin{aligned}
\left.\frac{\mathrm{d} \hat{c}}{\mathrm{~d} \hat{h}}\right|_{\alpha=0} & =\frac{1}{C^{\prime}(\hat{c})}>0 \\
\left.\frac{\mathrm{d} \hat{c}}{\mathrm{~d} \hat{h}}\right|_{\beta=0} & =\frac{g(\hat{h}) \cdot \hat{c} \cdot(1-F(\hat{c}))}{(1-G(\hat{h})) \cdot(1-F(\hat{c})+\hat{c} f(\hat{c}))}>0
\end{aligned}
$$

The sign of the first expression comes from the fact that expected membership costs are higher, the higher are charismatic requirements for sect leaders to enter into the market:

$$
C^{\prime}(\hat{c})=\frac{f(\hat{c})}{1-F(\hat{c})} \cdot[C(\hat{c})-\hat{c}]>0 .
$$

Intuitively, it makes sense that both curves are upward-sloped: The threshold willingness to pay of consumers in order to join a sect rises with the expected membership costs which themselves increase in charisma level (hence, the $\alpha$ locus is upward-sloped). On the other hand, the threshold level for sect leaders to enter into the religious market decreases with market size (since all costs are fixed costs) which itself is smaller the fewer customers join a sect (hence, the $\beta$-locus is also upward-sloped).

As a result, neither non-existence nor multiplicity of equilibria can be ruled out. If equilibria are not unique, they can be ranked in that a higher charisma threshold always goes along with a higher willingness-to-pay threshold. Recalling that $1-F(\hat{c})$ is the number of sects in the market and that $1-G(\hat{h})$ is the share of population that joins a sect, we can, thus, explain

- equilibria with a lot of sects, a high rate of sect membership in the population and rather low expected membership costs (as also lowprofile sect leaders with low charisma enter the market); and 
- equilibria with a small number of sects, a low rate of membership but rather high expected membership costs (as only high-profile sect leaders enter the market).

We call the former type of equilibria sectarian and the latter type secular. While general results on existence or multiplicity of equilibria are not available, we can, however, exemplify the multitude of outcomes our simple model is able to generate by assuming that the distributions of charisma across sect leaders and of consumer types are both uniform. I.e., we assume that variable $h$ be uniformly distributed over an interval $[a, b] \subset R$ with $b>a$. We further assume that $c$ is uniformly distributed on $[0,1]$ which is an innocuous normalization. ${ }^{12}$ The religious market is now characterized by

$$
C(\hat{c})=\frac{1+\hat{c}}{2}, \quad \widehat{h}=\frac{1+\hat{c}}{2}, \quad n=\frac{b-\frac{1+\hat{c}}{2}}{b-a}
$$

and hence (3) and (4) read as

$$
\begin{aligned}
\alpha(\hat{h}, \hat{c}) & =\widehat{h}-\frac{1+\hat{c}}{2}=0 \\
\beta(\hat{h}, \hat{c}) & =\frac{b-\widehat{h}}{b-a} \cdot \frac{\hat{c}}{1-\hat{c}}-d=0 .
\end{aligned}
$$

We first will show that equilibria in religious markets may well fail to exist at all. Consider, e.g., the special case $b=1$ where solving $\alpha=\beta=0$ in (6) and (7) requires

$$
\hat{c}=2 d(1-a) .
$$

Since $c$ is restricted to $[0,1]$, an equilibrium will thus fail to exist when the fixed cost $d$ of setting up a sect are too high or the minimum willingness to pay for sect membership (i.e., $a$ ) is too small.

Next, we investigate into the number of equilibria (existence provided). Combining (6) and (7) leads to a quadratic expression for $\hat{c}$ :

$$
\hat{c}=b-1 / 2+y \pm \sqrt{(b-1 / 2+y)^{2}-2 y}
$$

where we set:

$$
y:=(b-a) d .
$$

In the Appendix we demonstrate that with uniform distributions as specified above, equation (8) will have at most one solution (i.e., existing equilibria

\footnotetext{
${ }^{12}$ If $c$ were uniformly distributed over $\left[\gamma_{1}, \gamma_{2}\right]$, define $\tilde{c}:=\left(c-\gamma_{1}\right) /\left(\gamma_{2}-\gamma_{1}\right)$ which will be uniform on $[0,1]$. Then let $h$ undergo the same shift; this would not affect uniformity of its distribution. Proceed as below and afterwards re-transform the variables.
} 
are unique) whenever $b \geq 1$, i.e., if consumers' maximum willingness to pay for sect membership exceeds what the most demanding sect would at most charge for sect membership. Consider, however, the following numerical specification where $b<1$ :

$$
d=0.2, \quad a=0.5, \quad \text { and } \quad b=0.9 .
$$

Then (8) has two solutions:

$$
\hat{c}^{+}=0.7453 \text { and } \hat{c}^{-}=0.2147
$$

with corresponding values for $\hat{h}$ of

$$
\hat{h}^{+}=0.8727 \text { and } \quad \hat{h}^{-}=0.6073 .
$$

The first equilibrium is of the secular type: Only a small fraction of the population (less than seven percent) are a member of a sect, but pays a high price for that (and active sect leaders' charisma levels are high); the second equilibrium is of the sectarian type with a large number of sects of rather low average charisma, a large share of the population (almost three quarters) being enrolled in sects, and relatively low average costs.

Proposition 1 Even if the distributions of charisma across sect leaders and of consumer types are both uniform, multiple equilibria might arise in religious markets.

The observation that even with uniform type distributions equilibria in religious markets are not necessarily unique ${ }^{13}$ is in contrast to results obtained for standard lemons-type problems. E.g., Rose (1993) has shown by numerical analyses that equilibria in lemons markets are always unique when type distributions are uniform. ${ }^{14}$ Interestingly, our setting allows for the possibility of multiple equilibria even in the uniform case. The main feature that distinguishes our setting from the standard adverse-selection problem is that consumers pay for their purchases (here: sect membership) after uncertainty has been lifted and not, as in the lemons market, before the quality of the goods they purchase becomes known to them.

\footnotetext{
${ }^{13}$ Since (8) is a quadratic equation, uniform distributions can naturally not give rise to more than two equilibria. However, with other distributions there is nothing to prevent (3) and (4) to possess more than two solutions.

${ }^{14} \mathrm{~A}$ related finding is made by Gal-Or (1983) for an oligopoly model where both price and quality levels are determined at an equilibrium: The equilibrium will be unique when the distribution of the consumers' willingness to pay is uniform. Otherwise, multiple equilibria can arise.
} 
From an interpretative view the presence of two equilibria with the same underlying distribution of population suggests that different equilibria in the religious market need not reflect fundamental differences in populations, but may simply result from different contingencies. The structure of the market of religions does not necessarily bear a one-to-one relation to the distribution of religious traits, spiritual desires, or social needs in a population.

Moreover, recall that the fewer people actually join sects, the higher are expected membership costs imposed on those who join: ${ }^{15}$ The more secular a society the more demanding are those few sects that are actually active - and the more easily can these sects be regarded as exploiting or abusing their members. This observation might explain why attitudes towards sects are less lenient in "secular" countries than societies where larger parts of the population are religiously affiliated.

Finally, observe an interesting feature of equilibria obtained in the uniform case above for $b<1$. All sect leaders with higher charisma $c>\hat{c}$ will be active, in particular sect leaders with $c>b$. Their flock will, however, entirely consist of disappointed members whose willingness to pay $h$ falls short of membership cost $c$. Ex ante, however, these members joined in these sects voluntarily, engaging in a gamble with expected positive payoff. Hence, finding oneself trapped in a sect might be the unwarranted consequence of a rational gamble. Those not believing that human beings choose faith or sect affiliations in a rational way, may see members of high-demanding ("abusive") sects as victims who ought to be protected by the state. Different views on individual rationality translate into different policy stands: American policy of laissez-faire is more consistent with the assumption of full rationality, while more interventionist European policy would draw support from imperfect rationality.

\section{Welfare Results}

While establishing welfare comparisons between various equilibria is, in general, a demanding task, our model allows for a simple and clear-cut ranking of equilibria in the religious market:

Proposition 2 When there are multiple equilibria, they can be ranked so that the more active sects there are in an equilibrium, the higher are consumer surplus and producer surplus, and the lower is the average price of sect membership.

\footnotetext{
${ }^{15}$ Formally, this follows from the fact hat both the loci $\alpha=0$ and $\beta=0$ are upwardsloped and that expected membership cost increase in charismatic requirements; see (5).
} 


\section{The proof of this result is in the Appendix.}

As both consumer surplus and producer surplus are larger with more sects, so is social welfare. Our finding suggests that currently active sect leaders could benefit from increased competition by new entrants. As increased competition by less charismatic sect leaders results in lower average membership costs, it encourages entry by potential members staying initially outside the market.

Furthermore, we find that entry by less effective sect leaders requires an increase in average sect size $(1-F(\widehat{c})) /(1-G(\widehat{h}))$, thus boosting profits of more effective sect leaders. Market-creating effect, i.e., the increase in overall religious participation $1-G(\widehat{h})$ would then override market-stealing effect, triggered by the increase in the number of suppliers $1-F(\widehat{c})$.

For the so-called lemons problem, Wilson $(1979,1980)$ finds that higherprice equilibria are Pareto-better than lower price equilibria. Interpreting, in our framework, prices as expected membership costs, Proposition 2 seems to be markedly at odds with Wilson's result. However, the sects problem is qualitatively different from the standard lemons problem à la Akerlof (1970) or Wilson (1979). In a lemons market, price is handed over from buyer to seller before the buyer observes the quality of what he purchases. A higher price therefore always reflects that consumers expect the quality of the traded good to be higher. In particular, as an equilibrium price equals the marginal buyer's willingness-to-pay for the expected level of quality, total expected consumer surplus does not decline at higher prices. Sellers naturally prefer higher prices which then explains why high-price equilibria Pareto dominate low-price equilibria. In our setting, charismatic qualities only determine the extent to which sect leaders can ex post exploit sect members, and charisma does not positively enter consumers' utility functions. Unlike in the lemons problem, lower average quality - and, thus, expected membership costs and a larger number of sects - is welcomed by consumers (individual and total expected consumer surplus increase) and by sect leaders (the incumbents benefit from increased sect sizes and the new entrants would otherwise stay out of the market).

An important caveat of our welfare results is that they refer to ordinary and rather mainstream sects that charge a membership fee as an ex-post compensation for providing religious services. In an amplified manner, the same mechanism can also be exploited by destructive religious sects and even terrorist groups. At worst, such groups end up promoting violence against other people or suicide of its members (think, e.g., of Hamas, Aum Shinri Kyo, or the Davidian Branch). Berman (2003) explains the emergence of radical religious militias along these lines. 


\section{Concluding Remarks}

In this paper, we make several contributions to the economic theory of religion: First, we offer a rational choice explanation for the puzzlingly large differences in religious market structures and membership across the United States or between the United States and most European countries. By showing that religious markets are typically characterized by indeterminacy, we complement (and partly challenge) the so-called supply-side theory of religious markets according to which different patterns of religious activities in different countries are mainly the consequence of different supplies in the religious market. Our observation that a single set of initial (demand and supply) conditions can give rise to a multitude of equilibrium outcomes with high or low rates of religious participation, larger or smaller sects, and higher or lower average costs of sect membership lends to a further explanation for observed diversity in religious patterns: that of a mere eventuality or contingency.

Second, we enrich the theory of religious markets by considering free entry decisions of potential religious leaders. So far, the supply side in religious market (the set of active religious entrepreneurs) has always been assumed to be parametrically fixed. For example, in a recent contribution, Barros and Garoupa (2002) study the interaction in the religious market with an incumbent (even, monopoly) church. While their focus is on how an existing church locates in a policy space, we endogenize entry into the religious market. We are not aware of any previous literature taking this step, which we view to be crucial in understanding the religious market in the United States and other countries without state-endowed monopoly churches. An interesting topic for further research would be to combine the spatial-location model by Barros and Garoupa (2002) with our model of endogenous entry.

Third, we demonstrate that membership in an "abusive" and exploiting sect need not be an irrational act. Wishing never to have entered a certain sect can just be the undesired consequence of an ex-ante perfectly rational gamble, which questions certain interventionist policy recommendations asking for state regulation. There are, however, certain steps that a government could take to curb the excesses of abusive sect leaders without infringing religious freedom. A somewhat controversial policy tool would be to limit the tax deductibility of contributions towards religious groups, or even rendering religious groups tax liable, if the income they collect exceeds a certain threshold per member. While many religious groups might denounce such a change, curbing the possibility of more charismatic sect leaders to extract contributions from their flock could even invigorate the religious market. By lowering expected membership costs, taxing excessive profits by sect leaders 
could lead more people to join a sect, thereby ending up encouraging entry to religious market by less charismatic and monetarily less demanding potential sect leaders.

Our fourth contribution consists of welfare analysis. We establish general conditions under which an equilibrium with a larger number of sects results in higher aggregate consumer and producer surpluses. We even find that a move to an equilibrium with a larger share of potential sect leaders entering the religious market is accompanied by an increase in average sect size and in profits made by initially active sect leaders. Market-creating effects of sectarian competition exceed market-stealing effects.

Fifth, we tentatively relate our findings to the emergence of political attitudes concerning the necessity of policing religious markets. We demonstrate that in more secular societies (like the European ones) sects impose, on average, heavier burdens on their members than in societies with higher rates of religious participation (like the United States). Fears that sect leaders might (abusively) extract significant resources and control the private lives of their members would then appear, on average, more justified in a secular than in a sectarian equilibrium. Differences in American and European perception of sects might, therefore, need not reflect differences in underlying preferences or market basics, but may already arise from living in societies with different equilibria.

\section{Appendix}

\section{Uniqueness of equilibrium for uniform distributions if} $b \geq 1$.

Recall (8), the equilibrium condition for $\hat{c}$ :

$$
\hat{c}=z+y \pm \sqrt{(z+y)^{2}-2 y}
$$

where we set:

$$
z:=b-1 / 2 \text { and } y:=(b-a) d .
$$

Denote by $\hat{c}^{+}$and $\hat{c}^{-}$the solutions to $\hat{c}$ when, respectively, the plus- and the minus-sign are applied in (8). By $b \geq 1, z \geq 0.5$. There are two cases to be distinguished: 
Case 1: $z>1 / 2$. Calculate that:

$$
\begin{aligned}
\hat{c}^{+} & =z+y+\sqrt{(z+y)^{2}-2 y}>z+y+\sqrt{(z-y)^{2}} \\
& =z+y+|z-y| \\
& =\left\{\begin{array}{lll}
2 z & \text { if } & z \geq y \\
2 y & \text { if } & y \geq z
\end{array}\right. \\
& \geq 2 z>1
\end{aligned}
$$

which contradicts the restriction that $\hat{c}$ is bounded from above by 1 . Hence, equilibrium can (at most) occur at $\hat{c}^{-}$.

Case 2: $z=1 / 2$. In this case, $(z+y)^{2}-2 y=\left(\frac{1}{2}-y\right)^{2}$, and $b=1$. We can now separate three cases.

(i) $y<\frac{1}{2}$ :

$$
\hat{c}=\frac{1}{2}+y \pm\left(\frac{1}{2}-y\right) .
$$

Now $\hat{c}^{+}=1$ and $\hat{c}^{-}=2 y$, the latter being strictly between 0 and 1. In the former case, we get $\hat{h}=1$, implying that nobody joins the sect. Hence, an equilibrium can at most occur with $\hat{c}^{-}=2 y$. Such an equilibrium will exist if the attending value of $\hat{h}$, namely $\hat{h}=$ $1 / 2+(1-a) d$ does not exceed 1 .

(ii) $y=\frac{1}{2}$ : Then, $\hat{c}^{-}=\hat{c}^{+}=1$ and $\hat{h}=1-$ which cannot be an equilibrium (see above). Thus, an equilibrium with any sect fails to exist here.

(iii) $y>\frac{1}{2}$ :

$$
\hat{c}=\frac{1}{2}+y \pm\left(y-\frac{1}{2}\right)
$$

Now $\hat{c}^{+}=2 y$, violating the constraint that $\hat{c} \leq 1$. We are left with $\hat{c}^{-}=1$, which cannot be an equilibrium as $\hat{h}>1$ then. Hence, again no equilibrium exists in this case.

\section{Proof of Proposition 2}

Consider two alternative equilibria, called $\varphi_{1}$ and $\varphi_{2}$, such that the number of sects is larger in $\varphi_{2}: \hat{c}_{1}>\hat{c}_{2}$. Notice from (2) that the expected membership cost is decreasing in the number of active sect leaders: $C\left(\hat{c}_{2}\right)<C\left(\hat{c}_{1}\right)$. Thus, individuals who are sect members in $\varphi_{1}$ can receive services by sects at a lower price in $\varphi_{2}$. These individuals will therefore be sect members in $\varphi_{2}$, too, and will enjoy a higher consumer surplus then. Moreover, overall participation 
will be higher in $\varphi_{2}$ than in $\varphi_{1}: \widehat{h}_{2}<\widehat{h}_{1}$. The additional sect members receive non-negative expected surplus in $\varphi_{2}$, compared to zero in $\varphi_{1}$. Hence, consumer surplus is higher in $\varphi_{2}$ than in $\varphi_{1}$.

When $\widehat{c}$ decreases, equality in (4) can only be maintained if average sect size $(1-F(\hat{c})) /(1-G(\hat{h}))$ increases. Producer surplus of those sects active in $\varphi_{1}$ is then larger in $\varphi_{2}$, as they receive the same tithe per member from a larger group of members. Additional sects in $\varphi_{2}$ only enter if they earn non-negative profits, implying that producer surplus in $\varphi_{2}$ is larger than in $\varphi_{1}$.

QED

\section{References}

Abercrombie, Nicholas, Stephen Hill, and Bryan S. Turner (2000). Dictionary of Sociology. 4th ed. (London: Penguin Reference Books).

adherents.com (2003). http://www.adherents.com.

Akerlof, George (1970). "The Market for 'Lemons': Qualitative Uncertainty and the Market Mechanism," Quarterly Journal of Economics, vol. 84, pp. $488-500$.

ARIS (2001). http://www.gc.cuny.edu/studies/keyfindings.htm.

Azzi, Corry, and Ronald G. Ehrenberg (1975). "Household Allocation of Time and Church Attendance," Journal of Political Economy, vol. 83, pp. 27-56.

Barros, Pedro Pita and Nuno Garoupa (2002). "An Economic Theory of Church Strictness," The Economic Journal, vol. 112, pp. 559-576.

Berman, Eli (2000). "Sect, Subsidy, and Sacrifice: An Economist's View of Ultra-Orthodox Jews," Quarterly Journal of Economics, vol. 115, pp. 905-953.

Berman, Eli (2003). "Hamas, Taliban and the Jewish Underground: An Economist's View of Radical Religious Militias," NBER Working Paper 10004, National Bureau of Economic Research, Cambridge.

Bruce, Steve (1999). Choice and Religion. A Critique of Rational Choice Theory. (Oxford: Oxford University Press).

Chaves, Mark, and David E. Cann (1992). "Regulation, Pluralism, and Religious Market Structure. Explaining Religion's Vitality," Rationality and Society, vol. 4, pp. 272-290. 
Enquete Commission (1998). Final Report of the Enquete Commission on "So-called Sects and Psychogroups": New Religious and Ideological Communities and Psychogroups in the Federal Republic of German. (Bonn: Deutscher Bundestag).

Gal-Or, Esther (1983). "Quality and Quantity Competition," Bell Journal of Economics, vol. 14, pp. 590-600.

GESIS - German Social Science Infrastructure Services e.V. (2004). At http://www.gesis.org/en/social_monitoring/social_indicators/Data/Sys

Iannaccone, Laurence R. (1991). "The Consequences of Religious Market Structures: Adam Smith and the Economics of Religion," Rationality and Society, vol. 3, pp. 156-177.

Iannaccone, Laurence R. (1992a). "Religious Markets and the Economics of Religion," Social Compass, vol. 39, pp. 123-131.

Iannaccone, Laurence R. (1992b). "Sacrifice and Stigma: Reducing FreeRiding in Cults, Communes, and Other Collectives," Journal of Political Economy, vol. 100, pp. 271-291.

Iannaccone, Laurence R. (1998). "Introduction to the Economics of Religion," Journal of Economic Literature, vol. 36, pp. 1465-1496.

Kent, Stephen A. (2001). "The French and German versus American Debate over 'New Religions', Scientology, and Human Rights," Marburg Journal of Religion, vol. 6, pp. 1-13.

Messner, Francis (1999). "La Législation Cultuelle des Pays de l'Union Européenne face aux Groupes Sectaires". In: Champion, Françoise and Martine Cohen (eds.), Sectes et Démocratie. (Paris: Editions du Seuil), pp. 331-358.

Pascal, Blaise (1995) [1660]. Pensées (translated by A.J. Krailsheimer), (London: Penguin Classics).

Rose, Colin (1993). "Equilibrium and Adverse Selection," RAND Journal of Economics, vol. 24, pp. 559-569.

Smith, Adam (1999) [1776]. The Wealth of Nations. Books IV-V. (London: Penguin Classics).

Stark, Rodney, and William S. Bainbridge (1996). A Theory of Religion. (New Brunswick: Rutgers University Press). 
Stark, Rodney, Roger Finke, and Laurence R. Iannaccone (1995). "Pluralism and Piety: England and Wales, 1851," Journal for the Scientific Study of Religion, vol. 34, pp. 431-444.

Stark, Rodney, and Laurence R. Iannaccone (1994). "A Supply-Side Reinterpretation of the 'Secularization' of Europe," Journal for the Scientific Study of Religion, vol. 33, pp. 230-252.

The Guardian, "France to crack down on sects," (June 14, 2000). Available at http://www.guardian.co.uk/international/story/0,3604,331743,00.html.

United States Department of State, International Religious Freedom Report 2002. Available at http://www.state.gov/g/drl/rls/irf/2002/13936.htm.

Wilson, Charles A. (1979). "Equilibrium and Adverse Selection," American Economic Review, vol. 69, pp. 313-317.

Wilson, Charles A. (1980). "The Nature of Equilibrium in Markets with Asymmetric Information," Bell Journal of Economics, vol. 11, pp. 108-130. 


\section{CESifo Working Paper Series}

(for full list see www.cesifo.de)

1175 Chang Woon Nam and Doina Maria Radulescu, Types of Tax Concessions for Attracting Foreign Direct Investment in Free Economic Zones, April 2004

1176 M. Hashem Pesaran and Andreas Pick, Econometric Issues in the Analysis of Contagion, April 2004

1177 Steinar Holden and Fredrik Wulfsberg, Downward Nominal Wage Rigidity in Europe, April 2004

1178 Stefan Lachenmaier and Ludger Woessmann, Does Innovation Cause Exports? Evidence from Exogenous Innovation Impulses and Obstacles, April 2004

1179 Thiess Buettner and Johannes Rincke, Labor Market Effects of Economic Integration The Impact of Re-Unification in German Border Regions, April 2004

1180 Marko Koethenbuerger, Leviathans, Federal Transfers, and the Cartelization Hypothesis, April 2004

1181 Michael Hoel, Tor Iversen, Tore Nilssen, and Jon Vislie, Genetic Testing and Repulsion from Chance, April 2004

1182 Paul De Grauwe and Gunther Schnabl, Exchange Rate Regimes and Macroeconomic Stability in Central and Eastern Europe, April 2004

1183 Arjan M. Lejour and Ruud A. de Mooij, Turkish Delight - Does Turkey's accession to the EU bring economic benefits?, May 2004

1184 Anzelika Zaiceva, Implications of EU Accession for International Migration: An Assessment of Potential Migration Pressure, May 2004

1185 Udo Kreickemeier, Fair Wages and Human Capital Accumulation in a Global Economy, May 2004

1186 Jean-Pierre Ponssard, Rent Dissipation in Repeated Entry Games: Some New Results, May 2004

1187 Pablo Arocena, Privatisation Policy in Spain: Stuck Between Liberalisation and the Protection of Nationals' Interests, May 2004

1188 Günter Knieps, Privatisation of Network Industries in Germany: A Disaggregated Approach, May 2004

1189 Robert J. Gary-Bobo and Alain Trannoy, Efficient Tuition Fees, Examinations, and Subsidies, May 2004 
1190 Saku Aura and Gregory D. Hess, What's in a Name?, May 2004

1191 Sjur Didrik Flåm and Yuri Ermoliev, Investment Uncertainty, and Production Games, May 2004

1192 Yin-Wong Cheung and Jude Yuen, The Suitability of a Greater China Currency Union, May 2004

1193 Inés Macho-Stadler and David Pérez-Castrillo, Optimal Enforcement Policy and Firms' Emissions and Compliance with Environmental Taxes, May 2004

1194 Paul De Grauwe and Marianna Grimaldi, Bubbles and Crashes in a Behavioural Finance Model, May 2004

1195 Michel Berne and Gérard Pogorel, Privatization Experiences in France, May 2004

1196 Andrea Galeotti and José Luis Moraga-González, A Model of Strategic Targeted Advertising, May 2004

1197 Hans Gersbach and Hans Haller, When Inefficiency Begets Efficiency, May 2004

1198 Saku Aura, Estate and Capital Gains Taxation: Efficiency and Political Economy Consideration, May 2004

1199 Sandra Waller and Jakob de Haan, Credibility and Transparency of Central Banks: New Results Based on Ifo's World Economicy Survey, May 2004

1200 Henk C. Kranendonk, Jan Bonenkamp, and Johan P. Verbruggen, A Leading Indicator for the Dutch Economy - Methodological and Empirical Revision of the CPB System, May 2004

1201 Michael Ehrmann, Firm Size and Monetary Policy Transmission - Evidence from German Business Survey Data, May 2004

1202 Thomas A. Knetsch, Evaluating the German Inventory Cycle - Using Data from the Ifo Business Survey, May 2004

1203 Stefan Mittnik and Peter Zadrozny, Forecasting Quarterly German GDP at Monthly Intervals Using Monthly IFO Business Conditions Data, May 2004

1204 Elmer Sterken, The Role of the IFO Business Climate Indicator and Asset Prices in German Monetary Policy, May 2004

1205 Jan Jacobs and Jan-Egbert Sturm, Do Ifo Indicators Help Explain Revisions in German Industrial Production?, May 2004

1206 Ulrich Woitek, Real Wages and Business Cycle Asymmetries, May 2004

1207 Burkhard Heer and Alfred Maußner, Computation of Business Cycle Models: A Comparison of Numerical Methods, June 2004 
1208 Costas Hadjiyiannis, Panos Hatzipanayotou, and Michael S. Michael, Pollution and Capital Tax Competition within a Regional Block, June 2004

1209 Stephan Klasen and Thorsten Nestmann, Population, Population Density, and Technological Change, June 2004

1210 Wolfgang Ochel, Welfare Time Limits in the United States - Experiences with a New Welfare-to-Work Approach, June 2004

1211 Luis H. R. Alvarez and Erkki Koskela, Taxation and Rotation Age under Stochastic Forest Stand Value, June 2004

1212 Bernard M. S. van Praag, The Connexion Between Old and New Approaches to Financial Satisfaction, June 2004

1213 Hendrik Hakenes and Martin Peitz, Selling Reputation When Going out of Business, June 2004

1214 Heikki Oksanen, Public Pensions in the National Accounts and Public Finance Targets, June 2004

1215 Ernst Fehr, Alexander Klein, and Klaus M. Schmidt, Contracts, Fairness, and Incentives, June 2004

1216 Amihai Glazer, Vesa Kanniainen, and Panu Poutvaara, Initial Luck, Status-Seeking and Snowballs Lead to Corporate Success and Failure, June 2004

1217 Bum J. Kim and Harris Schlesinger, Adverse Selection in an Insurance Market with Government-Guaranteed Subsistence Levels, June 2004

1218 Armin Falk, Charitable Giving as a Gift Exchange - Evidence from a Field Experiment, June 2004

1219 Rainer Niemann, Asymmetric Taxation and Cross-Border Investment Decisions, June 2004

1220 Christian Holzner, Volker Meier, and Martin Werding, Time Limits on Welfare Use under Involuntary Unemployment, June 2004

1221 Michiel Evers, Ruud A. de Mooij, and Herman R. J. Vollebergh, Tax Competition under Minimum Rates: The Case of European Diesel Excises, June 2004

1222 S. Brock Blomberg and Gregory D. Hess, How Much Does Violence Tax Trade?, June 2004

1223 Josse Delfgaauw and Robert Dur, Incentives and Workers' Motivation in the Public Sector, June 2004

1224 Paul De Grauwe and Cláudia Costa Storti, The Effects of Monetary Policy: A MetaAnalysis, June 2004 
1225 Volker Grossmann, How to Promote R\&D-based Growth? Public Education Expenditure on Scientists and Engineers versus R\&D Subsidies, June 2004

1226 Bart Cockx and Jean Ries, The Exhaustion of Unemployment Benefits in Belgium. Does it Enhance the Probability of Employment?, June 2004

1227 Bertil Holmlund, Sickness Absence and Search Unemployment, June 2004

1228 Klaas J. Beniers and Robert Dur, Politicians' Motivation, Political Culture, and Electoral Competition, June 2004

1229 M. Hashem Pesaran, General Diagnostic Tests for Cross Section Dependence in Panels, July 2004

1230 Wladimir Raymond, Pierre Mohnen, Franz Palm, and Sybrand Schim van der Loeff, An Empirically-Based Taxonomy of Dutch Manufacturing: Innovation Policy Implications, July 2004

1231 Stefan Homburg, A New Approach to Optimal Commodity Taxation, July 2004

1232 Lorenzo Cappellari and Stephen P. Jenkins, Modelling Low Pay Transition Probabilities, Accounting for Panel Attrition, Non-Response, and Initial Conditions, July 2004

1233 Cheng Hsiao and M. Hashem Pesaran, Random Coefficient Panel Data Models, July 2004

1234 Frederick van der Ploeg, The Welfare State, Redistribution and the Economy, Reciprocal Altruism, Consumer Rivalry and Second Best, July 2004

1235 Thomas Fuchs and Ludger Woessmann, What Accounts for International Differences in Student Performance? A Re-Examination Using PISA Data, July 2004

1236 Pascalis Raimondos-Møller and Alan D. Woodland, Measuring Tax Efficiency: A Tax Optimality Index, July 2004

1237 M. Hashem Pesaran, Davide Pettenuzzo, and Allan Timmermann, Forecasting Time Series Subject to Multiple Structural Breaks, July 2004

1238 Panu Poutvaara and Andreas Wagener, The Invisible Hand Plays Dice: Eventualities in Religious Markets, July 2004 